\section{Žarka Vujić}

Odsjek za informacijske i komunikacijske znanosti Filozofskog fakulteta Sveučilišta u Zagrebu

DOI:

10.17685/Peristil.60.19

\section{Josip Kovačić (1935.-2017.)}

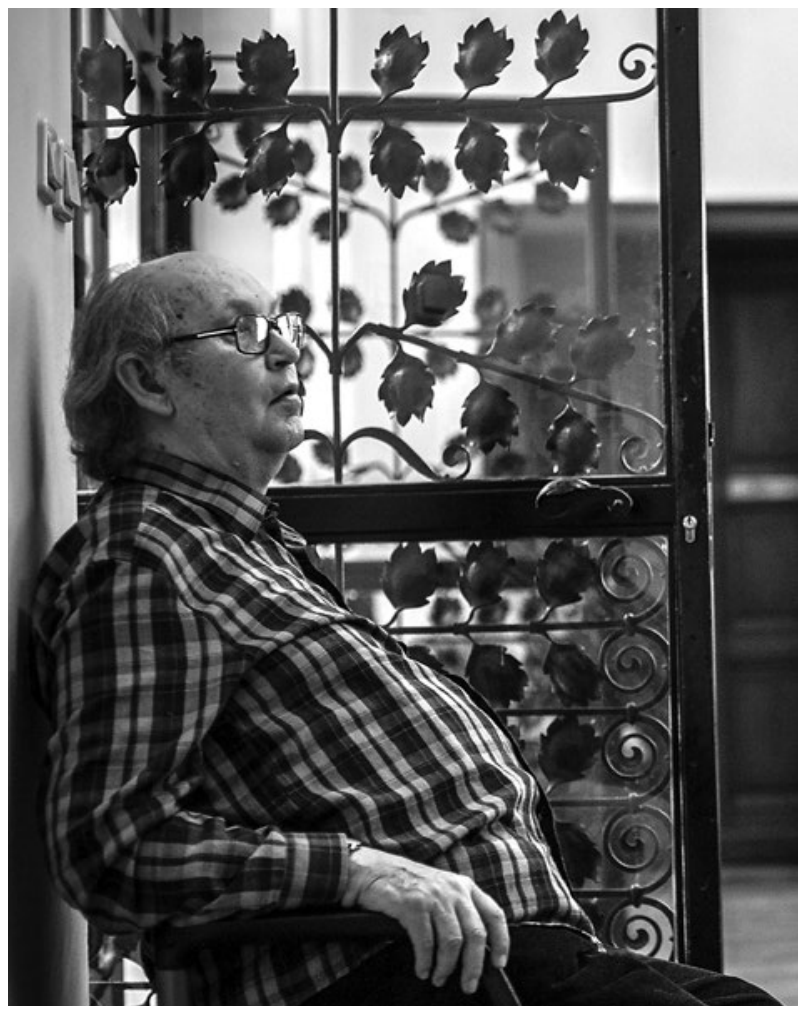

foto: Sanjin Kaštelan, MUO, 11. lipnja 2014

U ožujku 2017. godine otišao je tiho, doslovce do posljednjeg dana vezan uz svoje zbirke, dr. sc. Josip Kovačić, a kojeg smo i u akademskoj, i u muzejskoj i povjesničarsko-umjetničkoj zajednici na prvom mjestu doživljavali kao - Kolekcionara, odnosno kao stvaratelja respektabilnoga umjetničkog fundusa u koji smo posezali kad bismo istraživali pojedinačne ili skupne likovne fenomene, kad bismo pripremali manje ili veće umjetničke izložbe, kad bismo ulazili i sami u začudan svijet kolekcionara itd. Josip Kovačić rođen je u Čakovcu davne 1935. godine. Podaci o njegovu obrazovanju svjedoče kako je bila riječ o nadarenom djetetu i mladom čovjeku koji je uz uobičajeno školsko obrazovanje imao motivaciju ovladati i vještinom sviranja glasovira (varaždinska Glazbena škola) te poslije, školovanim plesnim pokretima odnosno baletom (Srednja baletna škola u Zagrebu). Dakle, već je u ranim formativnim godinama i sam doprinosio kulturnom stvaranju. Sve se to nastavilo i tijekom studija slavistike i francuskog jezika i književnosti na Filozofskom fakultetu (1954.-1959.). Poslije je radio kao profesor hrvatskog jezika u Čakovcu (Učiteljska škola, Gimnazija) i Zagrebu (IV. gimnazija), a boravak u Pečuhu u svojstvu lektora na Južnoslavenskoj katedri Visoke nastavničke škole (1971.-1975.) iskoristio je za izradu magistarske radnje pod naslovom Usmena narodna balada na mađarskom i hrvatskom ili srpskom jezičnom području, što će poslije proširiti u doktoratu vezanom uz poetsku vrstu balade i romance na istom korpusu (1980.). Dakle, pripadao je i znanstvenoj zajednici i znanstveni diskurs nije mu bio stran, a što smo često zaboravljali. 
Pisanje o osnovnom habitusu dr. sc. Josipa Kovačića prigodom posljednje izložbe iz kolekcionarovih zbirki (Donator $i$ donacija: ususret muzeju hrvatskih slikarica) nazvano je u jednom mrežnom napisu romansiranom biografijom. Suprotno, tekst i kolekcionarov portret načinjeni su na temelju osnovnih postavki istraživača sabiranja. Prva od njih govori kako je sabiranje u dječjem uzrastu rašireno, dapače daleko učestalije nego u odrasle populacije, no kako djeca ne sabiru antikvitete i umjetnička djela. Josip Kovačić sam je istaknuo da je prva njegova zbirka bila zbirka bilja i stvaranje vrta medimurskog bilja. Prihvatili smo njegov iskaz jer ga je višekratno potvrdio svojim djelovanjem, ponajviše posebnim senzibilitetom za temu cvijeća u umjetničkim djelima te detaljnim i preciznim opisivanjem slikanih biljnih vrsta (Ta imao je suradnicu botaničarku!). Potom je, a u realnosti vjerojatno usporedno s tim, počela nastajati za desetogodišnje dijete neuobičajena zbirka starina. Čini se kako je već tada nadređena kategorija bila ono što je u području baštine nezaštićeno i izvrgnuto devastaciji, a što se najbolje vidi iz svjedočenja o pretraživanju otpada kamene plastike na groblju u Mihovljanu i fotografija ugrađivanja spašenog u dvorištu vlastite kuće ili pomalo i gomilanja stilskog namještaja i ostalih antikviteta u rodnoj kući. Ta je zbirka bila doista vezana uz potonji prostor i 1976. oblikovatelj se odlučio njezinu građu što prodati što donirati Muzeju Medimurja.

No, tada je on već stvaratelj novih zbirki u Gradu Zagrebu u koji je preselio sredinom 60-ih 20. stoljeća. Sabiranje znatnog broja umjetnina u prvih desetak zagrebačkih godina, u skladu s financijskim mogućnostima, rađa mogućnost uočavanja dominantnog kriterija odabira - radovi žena umjetnica rođenih u 19. stoljeću - prema kojem se do kraja života kolekcionara formira javnosti najpoznatiji dio ovoga respektabilnog fundusa. U određivanju toga kriterija, kao i pri odabiru što kvalitetnijih radova, kolekcionar nije bio sam. Muzejski savjetnik Moderne galerije Darko Schneider u tome ga, potpuno nevidlijivo, prati čitavo vrijeme, a dr. sc. Vinko Zlamalik, ravnatelj Strossmayerove galerije HAZU, u prvim desetljećima stvaranja zbirke.

Godine 1988., većinom poradi pragmatičnih razloga, dolazi do donacije dijela zbirke od oko 1045 umjetnina Gradu Zagrebu. Donacija se s velikim odjekom i reprezentantima predstavlja javnosti u Umjetničkom paviljonu u Zagrebu. No, nažalost, taj čin ni nakon tri desetljeća nije uspio našim sinergijskim djelovanjem dovesti do osnutka Muzeja hrvatskih slikarica (rođenih u 19. stoljeću), a koji je mogao postati naglašeno razlikovnom gradskom muzejskom institucijom te dijelom jedinstvene kulturne ponude grada. Nismo u tom smislu ispunili očekivanja kolekcionara. Istovremeno je sam učinio sve da njegove zbirke nastave postojati i poslije njegove smrti i to doista jedinstveno i tako da je sam odgojio i pripremio svoga nasljednika, danas izdavača časopisa Kontura i knjiga s područja povijesti umjetnosti i trgovca umjetninama Zdravka Mihočinca.

Zajedno sa sabiranjem kao dominantnim odnosom prema svijetu koje je postalo, tipično za kolekcionare, gotovo prisilnom radnjom i za dr. sc. Josipa Kovačića, i poradi toga zahtijevalo svu njegovu životnu energiju, pa i odvajanje od obitelji i rani odlazak u mirovinu, odvijala se i aktivnost koja nije karakteristična za sve kolekcionare umjetničkih djela - što iscrpnije bilježenje svih podataka povezanih s pojedinom umjetninom (stvaranje intelektualnog dijela zbirke) te potpuno otvaranje zbirke stručnoj i ostalim javnostima, poticanje njezina istraživanja, posebice izlaganja u različitim oblicima - monografskim, tematskim i sl. Više od šezdeset izložbi nastalih isključivo na osnovi fundusa dr. sc. Josipa Kovačića, jednako kao i mnogobrojne izložbe u kojima su njegove umjetnine sudjelovale s ostalima, brojni katalozi, znanstveni i stručni radovi, monografije, pače i diplomski radovi itd. najjače svjedoče o tome, odnosno o potrebi vlasnika da njegova djela budu prisutna u javnosti i doprinesu kulturnom i znanstvenom životu. Naravno, sve to svjedoči i o komunikacijskom i znanstvenom kapitalu koji njegove zbirke, posebice djela žena umjetnica te 
zaboravljenih autora 20-ih i 30-ih godina 20. stoljeća, poput S. Lahovskog, B. Cara, J. Fabkovića i J. Leovića, predstavljaju.

Josip Kovačić iznimno je cijenio mišljenja povjesničara umjetnosti. Zanimljivo je i nama, višegodišnjim promatračima njegova djelovanja, muzejske profesionalce s kojima se najbolje mogao usporedivati u odnosu na brigu za baštinu, nadmoćno je stavljao u drugi plan. Jednako tako nije bio član Hrvatskoga muzejskog društva, nego upravo Društva povjesničara umjetnosti Hrvatske, a što je na svoj način također znakovito. I u osobnom razgovoru, koliko god znao i polemizirati s profesionalnim poznavateljima hrvatske umjetnosti, njihova je mišljenja s uvažavanjem citirao pri obradi svojih umjetnina i njihovo legitimiranje zbirke bilo mu je najvažnije.

Posljednjih nekoliko godina intenzivno se bavio proučavanjem biografije i opusa Slave Raškaj, a rezultat toga jedinstven je rukopis nastao iz pera i iz percepcije jednog kolekcionara. U njemu podosta polemizira s navodima akademika Matka Peića i donosi čitav niz njemu poznatih Slavinih djela: od akvareliranih ili crtanih remek-djela do dječjih crteža i slabijih putnih pejzažnih bilježaka i sl. No, ono što definitivno fascinira tijekom čitanja rukopisa jesu analize i opisi pojedinih radova, načinjeni na osnovi detaljnog sagledavanja i pomoću razvijenoga stručnog rječnika, sa suverenim poznavanjem tehnologije rada u pojedinim tehnikama, usporedivanjem pojedinih odrednica stvaralaštva Slave Raškaj i jedne Anke Krizmanić itd. Sve to daleko je jače od pomalo upitnog fabuliranja kod zaključivanja oko pojedinih biografskih detalja i svakako najzornije moguće pokazuje kako je jedan Kolekcionar protokom vremena i zahvaljujući svakodnevnom živom dodiru i istraživanju umjetničkih radova postao connoisseurom ili Poznavateljem. Kao takav ostat će u našem trajnom sjećanju. 